\title{
THE INFLUENCE OF ISLAMIC LEADERSHIP AND ISLAMIC WORK ETHICS ON EMPLOYEE PERFORMANCE OF ISLAMIC BANKS IN RIAU PROVINCE MEDIATED BY ISLAMIC ORGANIZATIONAL CULTURE
}

\author{
Zulfadli Hamzah \\ Doctoral Student \\ Department of Islamics Economic and Finance \\ Universitas Trisakti, Jakarta, Indonesia \\ E-mail: zulfadlihamzah@fis.uir.ac.id \\ Yuswar Zainal Basri \\ Professor \\ Department of Islamics Economic and Finance \\ Universitas Triskti, Jakarta, Indonesia \\ E-mail: warek1trisakti@gmail.com

\begin{abstract}
Zulhelmy
Associate Professor

Faculty of Economy and Business

Universitas Islam Riau, Indonesia

E-mail: zulhelmy@eco.uir.ac.id
\end{abstract}

\begin{abstract}
The purpose of this research is to examine the effect of Islamic leadership and Islamic work ethics on employee performance of Islamic banks in Riau province, whereby Islamic organizational culture became the mediator variable. This research employs the Structure Equation Model (SEM) based on Partial Least Square (PLS) with the help of SmartPLS 3.0 M3 software. The data were collected by using a questionnaire from 275 respondents. The respondent in this research was an employee of Islamic banks in Riau Province. The result showed that Islamic leadership, Islamic work ethics, and Islamic organizational culture positively and significantly influence on employee performance of Islamic banks in Riau province. On another side, the Islamic leadership mediated by Islamic organizational culture does not significantly influence on employee performance of Islamic Banks in Riau Provence. The finding of this research suggests that to enhance the role of Islamic leadership to create Islamic organization culture and Islamic work ethics increasingly would be an effect on employee performance of Islamic Bank in Riau province.
\end{abstract}

Keywords : Islamic Leadership, Islamic Work Ethics, Islamic Organizational Culture, Employee Performance, Islamic Bank.

JEL Classification Codes : M1, G21, M540. 


\section{INTRODUCTION}

Riau Province is one of the provinces located in Sumatera. Its territory is close to Jambi, West Sumatera, and North Sumatera. This province has a strategic location since it is near Singapore and Malaysia, so it becomes the main benefit for improving its economy. This also becomes a supporting factor in developing the Islamic banking industry in Riau Province. Let alone, the majority of the residents living in this province are Moslems with Malay culture that is identical to Islam, and it demands them to perform commercial and civil acts (muamalat) under Islamic law through sharia financial institutions. Hence, the supporting factors become the triggers of Islamic banking development in Riau. Based on the statistical data from the Financial Services Authority in 2020, there were 11 Sharia Bank branch offices, 29 sub-branch offices, and 8 cash offices of Islamic banks operated in Riau.

This province is also included in the big 10 provinces with the biggest Islamic banking assets in Indonesia with a percentage level of $1.40 \%$. Meanwhile, the total number of employees at Islamic banks in Riau can be seen as follows.

Table 1. Total Employee of Islamic Banks in Riau Province

\begin{tabular}{|c|l|c|}
\hline No & \multicolumn{1}{|c|}{ Banks } & Total Employee \\
\hline 1. & Bank Syariah Mandiri & 256 \\
\hline 2. & Bank Muammalat & 181 \\
\hline 3. & Bank BNI Syariah & 175 \\
\hline 4. & Bank BRI Syariah & 162 \\
\hline 5. & Bank BTPN Syariah & 94 \\
\hline 6. & Bank Mega Syariah & 73 \\
\hline & Total & $\mathbf{9 4 1}$ \\
\hline
\end{tabular}

From the description presented in the table above, it shows that the number of employees for each Islamic bank in Riau is as follows: 256 employees for Bank Syariah Mandiri, 181 employees for Bank Muamalat, 175 employees for Bank BNI Syariah, 162 employees for Bank BRI Syariah, 94 employees for Bank BTPN Syariah, and 73 employees for Bank Mega Syariah.

Even though the total of Islamic bank increases annually, a sad fact occurs that per March 2020, the market share of Islamic banking reached 5.99\% only from the national banking market share. This indicates that most of the national banking market share is still dominated by conventional banking. This happened due to several factors, such as low people's awareness of having transaction through Islamic banks, people still think that Islamic banks are similar to conventional banks, the information technology of Islamic banks is far below the conventional banks, the role of public figures and scholars who do not promote Islamic banks yet, the lack of support from the government as the stakeholder who issues regulations, and the limited human resources owned by Islamic banking. Besides, the human resource quality also affects the Islamic banking development in Indonesia (Tho'in, 2016). Therefore, the improvement of employee performance becomes a vital concern for Islamic banks.

The human resource problem in Islamic banking should be a serious concern for all of us since this internal factor plays an important role in developing Islamic banking industry in Indonesia. It has been known that the majority of Islamic banking human resources are from conventional banks, and they do not have the Sharia-based educational background, such as Bachelor of Islamic Economy and Bachelor of Islamic banking. As a result, their understanding 
of Islamic banking is still limited. On one hand, those who have a Bachelor's degree in Islamic Economy and Islamic banking cannot work in Islamic banking due to the high qualification and competitive recruitment test. Then, another human resource problem that needs to be considered is the high amount of employee turnover at Islamic banks due to the high work stress. Hence, they prefer resigning from their position as an Islamic bank employee. Those problems can affect the employee performance of Islamic bank.

Islamic banks need competent and professional human resources who do not only understand the business aspect of the banking industry but also have the competency in understanding the scientific aspect of Sharia. Those are required by Islamic banks to make the employee they recruit have good performance and high productivity. Therefore, the improvement of employee performance should be a vital concern for Islamic banks. Many factors can affect employee performance, such as Islamic organizational culture, Islamic leadership, and Islamic work ethics.

One of the values that can be developed in improving the performance is by developing Islamic values as organizational culture. In other words, the company can form Islamic organizational for improving performance (Suripto, 2016). Several studies also found that organizational culture could influence employee performance (Setyorini, Magfiroh, \& Farida, 2012; Wahyuningsih \& Basalamah, 2019; Marimin, 2011; Abadiyah \& Purwanto, 2016; Rachmanu \& Ridwan, 2018; Efrina, 2019). Meanwhile, the study conducted by Maula, Jamil, and Zuana (2020), and Kusumawati (2015) found that Islamic organizational culture could influence employee performance.

Leadership has an important role in bringing the success of an organization. A good leader can form a more conducive organizational culture so that the organization's visions and missions can be operated. This is in line with the result of the studies conducted by Abbasi et al., (2010); Faris \& Parry (2011); Randeree (2009) showing that leadership is a primary model and people who have direct and indirect effects on other people are the main elements in forming organization culture and employee performance. Several studies found that Islamic leadership could influence employee performance (Harahap, 2016; Wijayanti \& Wadji, 2012; Hakim, 2012; Fahrullah, 2018; Wijayanti \& Meftahudin, 2016). Meanwhile, the study conducted by Jannah, Suwardi and Iriyanto (2016) and Anam (2017) found that Islamic leadership did not influence employee performance.

Based on the Islamic perspective, a Moslem is demanded to have Islamic work ethics in working, whereby a Moslem should be a hard worker, productive, creative, and innovative to have a better performance. The study found that there was a positive effect between Islamic work ethics and Islamic work performance (Desky, 2014).

Work ethics owned by the employees will also form an organizational culture of an institution that will eventually improve employee performance. Kusumawati (2015) quantitatively found a result that there was a positive effect between Islamic work ethics and Islamic work performance in lecturers and employees at Universitas Islam Sultan Agung, Semarang. Some other studies also found the Islamic work ethics influenced employee performance (Mauliza, Yusuf \& Ilhamsyah, 2016; Citra, Purwadi \& Hakim, 2018; Layaman \& Maya, 2018; Indica, 2016). Meanwhile, a study conducted by Shafissalam and Azzuhri (2016) found that Islamic work ethics did not affect employee performance. 


\section{Islamic Leadership}

\section{LITERATURE REVIEW}

Leadership in the Islamic perspective based on Nawawi (1993) is someone's capacity in leading people to stay away from actions forbidden by Allah that are performed together or individually. In Islam, the leadership concept is believed to have a special value; it is not only the followers and the achievement of an organization's goals.

According to Mujiono (2002), leadership in Islam is a leader who performs the human functions as a caliphate on this earth and it should be done based on the Qur'an and hadith. Consequently, it can conclude that the Islamic leadership style is a way of leading people by a leader that can keep the trust and responsibilities to the members and Allah SWT based on Qur'an and hadith.

The holy prophet PBUH addressed all issues striking the right balance, applying his power positively with passion. Surely it was his farsightedness, compassion, and visionary leadership that helped Muslims develops their strength and base speedily. Then, True charisma from the Islamic perspective is in one's conduct (Islam \& Miajee, 2017). The Islamic leadership indicators can be found as follows:

- Loving truth and only having fear of Allah

- Upholding trusts and fulfilling people's trusts

- Sociable with other people

- Having an enthusiasm to go forward and have a good dedication

- Being responsible for decision-making

\section{Islamic Organizational Culture}

Islamic organizational culture that has been conducted will lead to Islamic perspective in the culture for providing a foundation or a basis that can make the style or the ways to be conducted collectively through an organization, to invite someone (a leader) to follow the teaching and the regulation in it. According to Mosque Management Institute, it is stated that an Islamic organization is an institution or organization with Islamic preaching in conducting preaching activities originating from Qur'an and Sunnahs of Prophet Muhammad with Islamic strategy, program, activity, and the development with ideology, goals, Visions, Missions, and Values. Denison and Misra (1995) formulated the indicators of organizational culture as follows: (1) involvement, (2) consistency, (3) adaptability, and (4) missions. Hakim (2011) stated that Islamic organizational culture is, for instance, based on three fundamental concepts, namely Tawheed (believing in the Oneness of Allah), Khilafah/Caliphate (leadership), and Adalah (fairness).

\section{Islamic Work Ethics}

According to Tasmara (2002), Islamic work ethic is a serious effort by exerting all assets, thoughts, and dhikr for actualizing or showing the sense of oneself as a servant of Allah that should conquer the world and place his/herself as a part of the best society (Khairul ummah). In other words, by working, a human can humanize him/herself. Therefore, it can conclude that Islamic work ethics is an attitude, character, and work habit reflected from the faith system/ 
Islamic Aqeeda (creed) for showing him/herself as a servant of Allah that should conquer the world and place his/herself as a part of the best society (Khairul ummah).

According to Asifudin (2004), the indication of people with high work ethics in general consists of the following characteristics:

- Active and like to work hard

- Having a high enthusiasm and being efficient

- Diligent and professional

- Efficient and Creative

- Honest, discipline, and responsible

- Independent

- Being rationale and having a strong vision further ahead

- Self-confident yet able to cooperate with other people

- Being simple, patient, and resilient

- Physically and mentally healthy

\section{Performance}

Nawawi (2004) stated that "Performance is the outcome of performing a certain task, both physical/material and non-physical/non-material. According to Simanjutak (2005)," performance is an achievement level of outcome for performing a certain task. Foster and Seeker (2001) stated that performance is the outcome achieved by someone based on an applicable measurement for a relevant work.

According to Mathis and Jackson (2002), employee performance is the effect of some contributions against an organization, such as:

- Work Quantity

- Work Quality

- Time Management

- Attendance rate

- Cooperation

\section{METHOD}

Generally, the type of this research is classified according to the objective, method, explanatory level, analysis, and types of data. Based on the method, this study was a survey in the form of explanatory study and hypothesis testing. In the survey, information was collected from the respondents using questionnaires and the data were collected from the sample or population (Sugiyono, 2005). Based on the explanatory level and the position of the variables, this study was categorized as a quantitative study. This study applied Partial Least Square (PLS)-based Structural Equation Model assisted by SmartPLS 3.0 M3 software. This study used primary data that were collected using questionnaires with total respondents of 273 people. The respondents in this study were the employees of Islamic banks in Riau province. 
Path Model

\section{RESULTS}

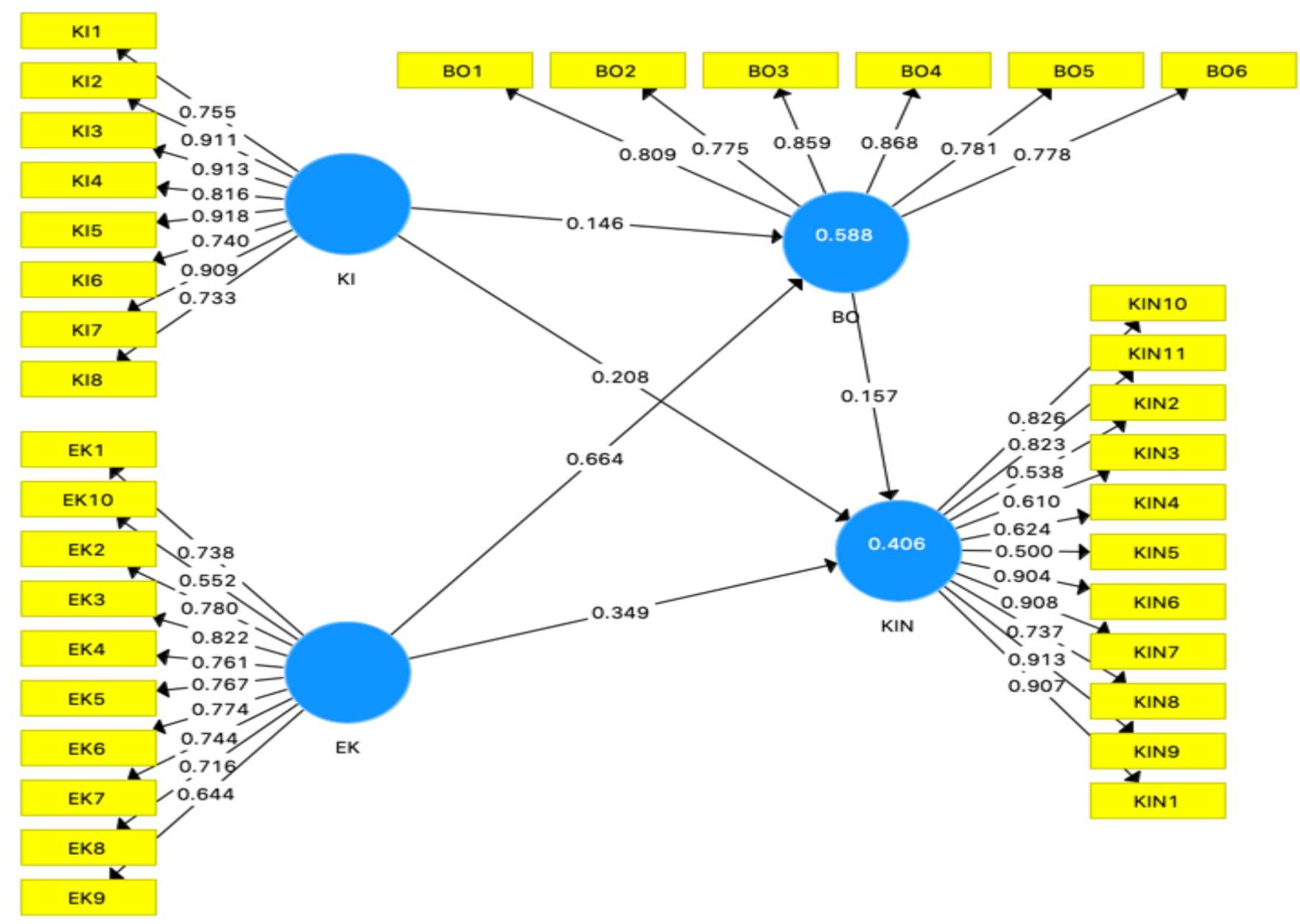

Figure 1. Path Model

\section{Significance Testing and Hypothesis Testing}

Direct Effect Analysis

Table 2. Direct Effect Analysis

\begin{tabular}{|l|l|l|l|l|l|l|}
\hline Hypotheses & $\begin{array}{l}\text { Original } \\
\text { Sample } \\
(\mathbf{O})\end{array}$ & $\begin{array}{l}\text { Sample } \\
\text { Mean } \\
(\mathbf{M})\end{array}$ & $\begin{array}{l}\text { Standard } \\
\text { Deviation } \\
\text { (STDEV) }\end{array}$ & $\begin{array}{l}\text { T-Statistics } \\
(\mid \mathbf{O} / \text { STDEV })\end{array}$ & P-Values & Description \\
\hline KI -> BO & 0.146 & 0.144 & 0.069 & 2.127 & 0.034 & Accepted \\
\hline KI -> KIN & 0.208 & 0.208 & 0.070 & 2.967 & 0.003 & Accepted \\
\hline EK -> BO & 0.664 & 0.667 & 0.059 & 11.282 & 0.000 & Accepted \\
\hline EK -> KIN & 0.349 & 0.352 & 0.070 & 5.011 & 0.000 & Accepted \\
\hline BO -> KIN & 0.157 & 0.157 & 0.067 & 2.345 & 0.019 & Accepted \\
\hline
\end{tabular}

Source: Result of Primary Data Processing, 2020 


\section{Indirect Effect Analysis}

Table 3. Indirect Effect Analysis

\begin{tabular}{|l|l|l|l|l|l|l|}
\hline Hypotheses & $\begin{array}{l}\text { Original } \\
\text { Sample } \\
(\mathbf{O})\end{array}$ & $\begin{array}{l}\text { Sample } \\
\text { Mean (M) }\end{array}$ & $\begin{array}{l}\text { Standard } \\
\text { Deviation } \\
(\text { STDEV) }\end{array}$ & $\begin{array}{l}\text { T-Statistics } \\
(\mid \mathbf{O} / \text { STDEV })\end{array}$ & P-Values & Description \\
\hline $\begin{array}{l}\text { KI }>\text { BO -> } \\
\text { KIN }\end{array}$ & 0.023 & 0.023 & 0.015 & 1.525 & 0.128 & Rejected \\
\hline $\begin{array}{l}\text { EK -> BO -> } \\
\text { KIN }\end{array}$ & 0.105 & 0.105 & 0.046 & 2.278 & 0.023 & Accepted \\
\hline
\end{tabular}

Source: Result of Primary Data Processing, 2020

\section{DISCUSSION}

\section{The Influence of Islamic Leadership on Islamic Organizational Culture in Employees of Islamic Banks}

Based on the analysis result, it can be seen in Table 2 that the path coefficient value for Islamic leadership against Islamic organizational culture was 0.146 with a calculated-t value of 2.217. The value is higher than the tabulated-t of 1.974. This result proves the significant effect of Islamic leadership on Islamic organizational culture. The result of hypothesis 1 was $\mathrm{T}=0.003<$ 0.05, indicating that $\mathrm{Ho}$ is rejected and $\mathrm{Ha}$ is accepted. It indicates that Islamic leadership positively and significantly influenced Islamic organizational culture in employees of Islamic banks. This shows that Islamic leadership has a vital role in creating Islamic organizational culture in Islamic banks, whereby a leader in an Islamic bank can be a role model for his/her staff, and as a result, Islamic organizational culture can be created. Therefore, a leader in an Islamic bank should implement several characters, such as Siddiq (honest), Amanah (trusted), Fathonah (intellectual), and Tabligh (spread out of correct info) in working as has been performed by prophet Muhammad (peace be upon him). According to Robbins (2001), leaders or groups create and develop organizational culture. This organizational culture needs to be created and developed by a leader of an organization/a company or a certain group in the organization or company.

\section{The Influence of Islamic Leadership on the Employee Performance of Islamic Banks}

Based on the analysis result, it can be seen in Table 2 that the path coefficient value for Islamic leadership against Performance is 0.208 with a calculated-t value of 2.967 . The value is higher than the tabulated-t value of 1.974. This result proves that Islamic leadership significantly influenced the employee performance of Islamic banks. The result of hypothesis 2 was $\mathrm{T}=$ $0.034<0.05$, showing that Ho is rejected and $\mathrm{Ha}$ is accepted. This means that Islamic leadership positively and significantly influenced the employee performance of Islamic banks. This also indicates that Islamic leadership can improve the employee performance of Islamic banks, whereby the leaders of Islamic banks should be able to motivate and lead their staff to be more productive. Nawawi (1993) stated that Islamic leadership is someone's capacity in leading people to stay away from actions forbidden by Allah that are performed together or individually. In Islam, the leadership concept is believed to have a special value; it is not only the followers and the achievement of an organization's goals. 


\section{The Influence of Islamic Work Ethics on Islamic Organizational Culture in the Employees of Islamic Banks}

Based on the analysis result, it can be seen in Table 2 that the path coefficient value for Islamic work ethics against Islamic organizational culture was 0.664 with a calculated-t value of 11.282. The value is higher than the tabulated-t value of 1.974 . This result proves that compensation significantly influenced performance. The result of hypothesis I was $\mathrm{T}=0.000<0.05$, indicating that $\mathrm{Ho}$ is rejected and $\mathrm{Ha}$ is accepted. It means that Islamic work ethics positively and significantly influenced Islamic organizational culture in the employees of sharia banks. This also indicates that Islamic work ethics can create Islamic organizational culture in Islamic banks.

\section{The Influence of Islamic Work Ethics on the Employee Performance of Islamic Banks}

Based on the analysis result, it can be seen in Table 2 that the path coefficient value for Islamic work ethics against Performance was 0.349 with a calculated-t value of 5.011. The value is higher than the tabulated-t value of 1.974. This result proves that Islamic work ethics significantly influence performance. The result of hypothesis 1 was $\mathrm{T}=0.000<0.05$, indicating that $\mathrm{Ho}$ is rejected and $\mathrm{Ha}$ is accepted. It means that Islamic work ethics positively and significantly influenced employee performance of Islamic banks. This also indicates that Islamic work ethics can improve employee performance of Islamic banks.

\section{The Influence of Islamic Organizational Culture on the Employee Performance of Islamic Banks}

Based on the analysis result, it can be seen in Table 2 that the path coefficient value for Islamic organizational culture was 0.157 with a calculated-t value of 2.345 . The value is higher than the tabulated-t value of 1.974. This result proves that Islamic organizational culture significantly influenced Performance. The result of hypothesis 5 was $\mathrm{T}=0.019<0.05$, indicating that Ho is rejected and $\mathrm{Ha}$ is accepted. It means that Islamic organizational culture positively and significantly influenced the employee performance of Islamic banks.

\section{The Influence of Islamic Work Ethics on the Employee Performance of Islamic banks through Islamic Organizational Culture}

Based on the analysis result, it can be seen in Table 3 that the path coefficient value for Islamic work ethics against Employee Performance through Islamic organizational culture is 0.105 with a calculated-t value of 2.278. The value is higher than the tabulated-t value of 1.974 . This result proves that Islamic work ethics significantly influence Performance through Islamic organizational culture. The result of hypothesis 7 was $\mathrm{T}=0.023<0.05$, indicating that Ho is rejected and $\mathrm{Ha}$ is accepted. It means that Islamic work ethics positively and significantly influenced the Employee Performance of Islamic banks through Islamic organizational culture.

\section{The Influence of Islamic Leadership on the Employee Performance of Islamic banks through Islamic Organizational Culture}

Based on the analysis result, it can be seen in Table 3 that a path coefficient value for Islamic leadership against Performance through Islamic organizational culture is 0.023 with a calculated$t$ value of 1.525 . The value is lower than the tabulated-t value of 1.974 . This result proves that Islamic leadership did not significantly influence Performance through Islamic organizational culture. The result of hypothesis 6 was $\mathrm{T}=0.128>0.05$, indicating that Ha is rejected and Ho is 
accepted. It means that Islamic leadership did not positively and significantly influence the Employee Performance of Islamic banks through Islamic organizational culture.

\section{CONCLUSIONS}

Islamic leadership positively and significantly influences the Employee Performance of Islamic banks in Riau; Islamic leadership positively and significantly influences the Islamic organizational culture of Islamic banks in Riau; Islamic work ethics positively and significantly influence the Employee Performance of Islamic banks; Islamic work ethics positively and significantly influence the Islamic organizational culture of Islamic banks in Riau; Islamic organizational culture positively and significantly influences the Employee Performance of Islamic banks in Riau; Islamic leadership through Islamic organizational culture does not positively and significantly influence the Employee Performance of Islamic banks in Riau, and Islamic work ethics through Islamic organizational culture positively and significantly influence the Employee Performance of Islamic banks in Riau. This study concludes that Islamic banks in Riau province should always improve Employee performance by implementing the Islamic leadership concept while working and Islamic work ethics to all employees, as well as creating Islamic organizational culture.

\section{REFERENCES}

Abadiyah, R., \& Purwanto, D. (2016). The effect of Organizational Culture, Compensation on Work Satisfaction and Employee Performance of Islamic Bank. Jurnal Bisnis, Manajemen \& Perbankan, 2(02), 49-67. https://doi.org/10.21070/jbmp.v2i1.837.

Abbasi, A. S., Rehman, K. U., \& Abbasi, S. H. (2010). Welfare and protection model for organizational management: The Islamic perspective. African Journal of Business Management, 4(5), 739-747.

Anam, C. (2017). The effect of Islamic Leadership, Islamic Work Motivation on Employee Performance. Istithmar, 1(01), 11-29.

Asifudin, A. J. (2004). Islamic Work Ethics. Surakarta, ID : Penerbit Universitas Muhammadiyah Surakarta.

Citra, D. P.., Purwadi, A., \& Hakim, I. (2018). The Effect of Islamic Work Ethics and Organizational Culture on Employee Performance of Bank Tabungan Negara Syariah (BTN) KC Malang. Falah : Jurnal Ekonomi Syariah, 3(2), 24-33. https://doi.org/10.22219/jes.v3i2.6911.

Denison, D, \& Mishra, A. (1995). Toward a Theory of Organizational Culture and Effectiveness. Organization Science, 6(2), 204-223. https://doi.org/10.1287/orsc.6.2.204

Desky, H. (2014). The effect of Islamic Work Ethics and Leadership Style on Employee performance of Ayam Lepaas Restaurant in Lhokseumawe. INFERENSI: Jurnal Penelitian Sosial Keagamaan, 8(02), 459-478. https://doi.org/10.18326/infs13.v8i2.459478 
Efrina, L. (2019). Islamic Work Ethics and Organizational Culture : Its Effect on Employee Performance of Islamic Multifinance. Equilibrium Jurnal Ekonomi Syariah, 7(02), 259271. http://doi.org/10.21043/equilibrium.v7i2.5808

Fahrullah, A. (2018). The Effect of Islamic Leadership on Motivation, Performance and Islamic Welfare. Al-Uqud: Journal of Islamic Economics, 2(02), 121-140. http://doi.org/10.26740/al-uqud.v2n2.p121-140

Faris, N., \& Parry, K. (2011). Islamic Organizational Leadership within a Western Society: The Problematic Role of External Context. The Leadership Quarterly, 22(1), 132-151. https://doi.org/10.1016/j.leaqua.2010.12.012

Hakim, A. (2012). The Implementation of Islamic Leadership and Islamic Organizational Culture and Its Influence on Islamic Working Motivation and Islamic Performance PT Bank Mu'amalat Indonesia Tbk. Employee in the Central Java. Asia Pacific Management Review, 17(01), 77-90. https://doi.org/10.6126/APMR.2012.17.1.05

Hakim, L. (2011). Building a Superior Organizational Culture as An Effort to Improve Employee Performance in the Competitive Era. BENEFIT Jurnal Manajemen dan Bisnis, 15(2), 148-158. http://doi.org/10.23917/benefit.v15i2.1342.

Harahap, S. (2016). The Influence of Islamic Leadership and Work Motivation on Employee Performance at PT. Bank Syariah Mandiri, Tbk Sukaramai Medan Sub-Branch Office. Human Falah, 3(02), 253-270.

Indica, I. W. M. (2016). The Influence of Islamic Work Ethics and Transformational Leadership Style on Organizational Commitment and Employee Performance. Jurnal Ilmiah Mahasiswa FEB Universitas Brawijaya, 2(2).

Islam, K.M.A., \& Miajee, M.R.K. (2017). An Islamic Prespective of Leadership. International Journal of Islamic Business \& Management, 1(1), 14-16.

Jannah, M., Suwardi, Iriyanto, S. (2016). Analysis of Islamic Leadership on Employee Performance (Case Study at PT. Bank Mumalat Indonesia Tbk, Semarang Branch). Value Assed, Makalah Ekonomi Dan Bisnis, 12(01), 16-30.

Kusumawati, D. A. (2015). Improving Islamic Performance Behavior with Islamic Organizational Culture as a Moderating Variable. Proceeding of the 2 nd Conference in Busineess, Accounting and Managgement (pp. 233-242). Universitas Islam Sultan Agung, Jawa Tengah, Indonesia. May $1^{\text {st }}$.

Layaman \& Maya., J. (2018). The Influence of Islamic Work Culture and Work Ethic on Employee Performance at Bank Syariah Mandiri Cirebon Branch. Journal of Strategic Management, 1(1). : https://doi.org/10.25134/ijsm.v1i1.843. 
Marimin, A. (2011). The Influence of Leadership Style, Work Motivation, and Organizational Culture on Employee Performance at Bank Muamalat Indonesia Surakarta Branch. Jurnal Muqtasid, 2(20), 23-37. https://doi.org/10.18326/muqtasid.v2i1.23-37

Mathis, R. L., \& Jackson, J. H. (2002). Human Resource Management. Jakarta, ID : Salemba Empat.

Maula, L. H., Jamil, S., \& Zuana., M. M. (2020). The Influence of Islamic Organization Culture and Employee Welfare on Employee Performance at PT. Bank Syariah Mandiri Sidoarjo Branch Office. Al-Tsiqoh : Jurnal Ekonomi dan Dakwah Islam, 5(01), 80-91. https://doi.org/10.1234/altsiq.v5i1.698

Mauliza, P., Yusuf, R., \& Ilhamsyah, T. R. (2016). The Influence of Islamic Work Ethic and Transformational Leadership Style on Organizational Commitment and Its Implications on the performance of Employees of Wilayatul Hisbah Banda Aceh. Jurnal Prespektif Ekonomi Darussalam, 2(02), 185-200. https://doi.org/10.24815/jped.v2i2.6693

Mujiono, I. (2002). Leadership and Organization. Yogyakarta, ID : UII Press.

Nawawi, H. (1993). Leadership According to Islam. Yogyakarta, ID : Gajah Mada University Press.

Nawawi, H. (2004). Human Resource Management. Jakarta, ID : Ghalia Indonesia.

Rachmanu, E.D., \& Ridwan, A. A. (2018). Organizational Culture and Employee Performance : Islamic Economic Perspective. Ekspektra : Jurnal Bisnis dan Manajemen, 2(02), 170180. http:dx.doi.org/10.25139/ekt.v2i2.1222

Randeree, K. (2009). An Islamic Perspective on Leadership: Qur'anic World View on The Qualities of Leaders. Global Studies Journal, 2(02), 197-210.

Robbins, S. P. (2001). Organizational Behavior: Concept, Controversy, Application. Jakarta, ID : Prenhallindo.

Setyorini, C.T., Magfiroh, S., \& Farida, Y.N. (2012). The Influence of Organizational Commitment, and Work Engagement on Employee Performance of Baitul Mall Wa Tamwil, Media Riset Akuntansi, 2(01), 32-47.

Shafissalam, A., \& Azzuhri, M. (2016). The Influence of Islamic Work Ethic on Employee Performance at Indonesian Agro Niaga Cooperative (Kanindo) Syaria East Java. Jurnal Ilmiah Mahasiswa FEB Universitas Brawijaya, 2(2).

Sugiyono. (2005). Understanding Qualitative Research. Bandung, ID: CV. Alfabeta. 
Suripto, T. (2016). Strategies to Improve Company Performance Through Islamic Organization Culture. Jurnal Ekonomi Syariah Indonesia, 6(2), 144-153. http://dx.doi.org/10.21927/jesi.2016.6(2).\%25p

Tasmara, T. (2002). Building an Islamic Work Ethic. Jakarta, ID : Gema Insani Press.

Tho'in, M. (2016). Human Resources Competency of Sharia Bank Based on Islamic Sharia Principles (Case Study on BNI Syariah Surakarta). Jurnal Ilmiah Ekonomi Islam, 2(03), 158-171. http://dx.doi.org/10.29040/jiei.v2i03.49

Wahyuningsih., S.S., \& Basalamah, J. (2019). The Influence of Organizational Culture, Work Motivation and Islamic Work Ethics on Employee Performance of Bank Syariah Mandiri Makassar Branch. CESJ Center of Economic Student Journal, 2(02), 125-132.

Wijayanti, R., \& Meftahudin, M. (2016). Pengaruh kepemimpinan islami, motivasi dan kepuasan kerja terhadap kinerja karyawan dengan lama kerja sebagai variabel moderating. Jurnal Penelitian Dan Pengabdian Kepada Masyarakat UNSIQ, 3(3), 185192.

Wijayanti, R., \& Wajdi, F. (2012). The Influence of Islamic Leadership, Motivation And Job Satisfaction on Employee Performance with Long Work as Moderating Variables. Jurnal Ekonomi Manajemen Sumber Daya, 13(2), 108-115.

\section{Copyrights}

Copyright for this article is retained by the author(s), with first publication rights granted to the journal. This is an open-access article distributed under the terms and conditions of the Creative Commons Attribution license (http://creativecommons.org/licenses/by/4.0/) 